Sains Malaysiana 50(3)(2021): 821-828

http://dx.doi.org/10.17576/jsm-2021-5003-22

\title{
Effects of Apigenin, Luteolin, and Quercetin on the Natural Killer (NK-92) Cells Proliferation: A Potential Role as Immunomodulator
}

(Kesan Apigenin, Luteolin dan Quersetin terhadap Pertumbuhan Sel Pembunuh Asli (NK-92): Peranan Berpotensi sebagai Kawalan Imuniti)

Aung Myo oo@Mohd Hasym, Nasir Mat Nor*, Liyana HazWani Mohd Adnan, Nor Zidah Binti Ahmad, Abdi Wira Septama, Nik Nurul NaJihah, OHN MAR LWIN \& Nordin SimbaK

\section{ABSTRACT}

Cancer can be classified as a fourth leading cause of death in Malaysia. There is a continuous effort by scientists in finding alternative cure to cancer due to the known side effects of chemotherapy and radiation therapy as well as recurrences. One of the latest methods to kill cancerous cells is by using immune cells known as natural killer (NK) cells. Flavonoids such as flavone and flavonol are also known for their antioxidant, anti-inflammatory, immunomodulatory and anticancer properties. This study was carried out to determine the role of flavonoid compounds of apigenin, luteolin, and quercetin to facilitate the growth of NK-92 cells. NK-92 cell line was grown in tissue culture flasks containing $\alpha$-Minimum Essential Medium (MEM) medium enriched with L-glutamine, 12.5\% fetal bovine serum, 12.5\% horse serum, $0.2 \mathrm{mM}$ myo-inositol, $0.02 \mathrm{mM}$ folic acid, and 100 - $200 \mathrm{U} / \mathrm{mL}$ recombinant interleukin 2 (IL-2). The cell viability was determined via trypan blue staining where the cells were manually counted by a haemocytometer. The 3-(4,5-dimethylthiazol-2-yl)-2,5-diphenyltetrazolium bromide (MTT) assay was used to determine the cell viability of NK-92 cells after treatment with apigenin, luteolin, and quercetin. Results showed a dose-dependent proliferative effects of apigenin, luteolin, and quercetin on the proliferation of NK-92 cells showing the highest percentage of proliferation at $100 \mu \mathrm{g} / \mathrm{mL}$ for all compounds $(* P<0.05)$. However, exceeding the dose of $100 \mu \mathrm{g} / \mathrm{mL}$ had resulted in a decline of cell proliferations percentage. Based on these findings, flavonoid compounds comprising apigenin, luteolin and quercetin were able to induce proliferative effects on NK-92 cells.

Keywords: Apigenin; flavonoids; luteolin; natural killer cells; quercetin

\section{ABSTRAK}

Kanser boleh dikelaskan sebagai penyebab kematian ke-empat tertinggi di Malaysia. Usaha berterusan para saintis dalam mencari kaedah lain untuk merawat kanser disebabkan kesan sampingan yang diketahui berpunca daripada rawatan kemo dan radiasi serta pertumbuhan semula sel kanser. Salah satu daripada kaedah terkini untuk membunuh sel kanser adalah dengan menggunakan sel imun yang dikenali sebagai sel pembunuh asli (sel NK). Sekumpulan flavonoid seperti flavon dan flavonol juga dikenali dengan ciri antioksidan, antiradang, kawalan imuniti dan anti-kanser. Kajian ini telah dijalankan untuk menentukan peranan beberapa sebatian flavonoid iaitu apigenin, luteolin dan quersetin dalam membantu pertumbuhan sel NK-92. Sel NK-92 dibiakkan di dalam bekas tisu kultur yang mengandungi media $\alpha$-medium penting minimum ( $\alpha$-MEM) yang diperkaya dengan L-glutamin, 12.5\% serum sapi janin, 12.5\% serum kuda, 0.2 mM myo-inositol, 0.02 mM asid folik dan 100 - 200 U/mL rekombinan interleukin 2 (IL-2). Kadar pertumbuhan sel telah dikenal pasti melalui pewarnaan tripan biru dengan sel tersebut dihitung secara manual menggunakan hemositometer. Ujian 3-(4,5-dimetilthiazol-2-yl)-2,5-difeniltetrazolium bromida (MTT) telah digunakan untuk menentukan pertumbuhan sel NK-92 setelah dirawat dengan apigenin, luteolin dan quersetin. Keputusan menunjukkan bahawa kesan perkembangan pendosan-kerbergantungan daripada apigenin, luteolin dan quersetin ke atas pertumbuhan sel-sel NK-92 mempamerkan peratus pertumbuhan tertinggi pada $100 \mu \mathrm{g} / \mathrm{mL}$ untuk kesemua sebatian flavonoid $(* P<0.05)$. Walau bagaimanapun, kenaikan dos melebihi $100 \mu \mathrm{g} / \mathrm{mL}$ telah mengakibatkan pengurangan daripada peratusan pertumbuhan sel tersebut. Menerusi hasil kajian ini, sebatian flavonoid yang mengandungi apigenin, luteolin dan quersetin berupaya mempengaruhi kesan pertumbuhan sel NK-92.

Kata kunci: Apigenin; flavonoid; luteolin; sel pembunuh semulajadi; quersetin 


\section{INTRODUCTION}

At present, cancer is a major public health issue where number of cases are increasing at an alarming rate. Immune-cell-mediated therapy is fundamental to the treatment of various pathological conditions including cancer. Recent studies have discovered the potential of natural killer (NK) cells in immunotherapy by modulating the progression of cancer and various microbial infections. Said cells are also known for its applicability for innate immunity (Artis \& Spits 2015). Several studies conducted on animal models and human subjects have shown that the lack of NK cells activity or deficiency of NK cells would lead to the incidence of recurrent infection with higher chance of contracting cancer (Orange 2013).

The source of NK cells are lymphoid progenitor cells which accounted for $5-20 \%$ of peripheral blood lymphocyte. Although there has been a reviewed study on NK cells activation via natural compounds, vitamins and phytonutrients, there is insufficient evidence relating to the effect of flavonoids in particular to apigenin, luteolin and quercetion to promote NK cell proliferation (Grudzien \& Rapak 2018).

Several medicinal plants and fruits have been used for curative and preventive purposes centuries ago. One study indicated that consumption of varieties of fruits and vegetables in daily basis would improve not only human physical and mental wellbeing but also immunity (Thomson 2007). Scientists have been studying the effects of herbs in immunomodulatory function in order to use these plants as food supplement on the background idea to fight against infection and cancer. These naturally occurring botanical plants received greater focus due to their influential role in regulating immune functions (Darien \& Godbee 2014).

Flavonoid is one of the most common phytochemicals found in plants, and is highly important for their antioxidant, anti-inflammatory, anticancer, and immunomodulatory characteristics. There has been an inconsistent finding attributed to NK cells activation by flavonoids in which quercetin was reportedly showing no significant effects on the activity of NK cells (Exon et al. 1998; Heinz et al. 2010). Other studies have shown that flavonoid compounds such as luteolin and myrecitin further potentiate NK cells activity (Ismail et al. 2018; Lindqvist et al. 2014). As a mean to manage cancers, immunotherapy is gaining importance as it allows the use of such compounds to trigger immune cells proliferation. Therefore, it is an advantage to overcome the bouts of cancer recurrences by determining the use and effects of three flavonoids such as apigenin, luteolin and quercetin on the generations of NK cells.

\section{MATERIALS AND METHODS}

NK-92 cell lines were purchased from American Type Culture Collection (ATCC). These cells were frozen in cryotubes and stored in liquid nitrogen at $-196^{\circ} \mathrm{C}$ before subjected to thaw and culture. NK-92 cells were grown as monolayer cultures in $\alpha$ - Minimum Essential Medium $(\alpha$-MEM) medium (Nacalai Tesque Inc., USA) comprising $0.2 \mathrm{mM}$ myoinositol, $0.1 \mathrm{mM}$ 2-mercaptoethanol, 0.02 $\mathrm{mM}$ folic acid, $100-200 \mathrm{U} / \mathrm{mL}$ human recombinant Interleukin-2 (IL-2) (Elabscience, USA), 12.5\% fetal bovine serum (FBS) (ATCC) and $12.5 \%$ horse serum (ATCC). The cells were incubated at $37^{\circ} \mathrm{C}$ in humidified $5 \% \mathrm{CO}_{2}$ incubator (Galaxy $170 \mathrm{R}$, New Brunswick, Scotland). The cell viability was assessed by trypan blue staining and manually counted using a haemocytometer.

\section{FLAVONOID SOLUTION PREPARATION}

Apigenin, luteolin, and quercetin (Sigma-Aldrich, Saint-Quentin-Fallavier) was dissolved in $100 \%$ dimethylsulfoxide (DMSO) (Merck, Germany) as a $1 \mathrm{mg} /$ $\mathrm{mL}$ stock concentration. Prior to use, the samples were diluted with $\alpha$-MEM medium to a final concentration of $400 \mu \mathrm{g} / \mathrm{mL}$. All samples were prepared and freshly diluted before the experiment starts.

\section{DOSE RESPONSE STUDY (MTT ASSAY)}

The dose response study of apigenin, luteolin and quercetin were evaluated based on the colorimetric 3-(4,5-dimethylthiazol-2-yl)-2,5-diphenyltetrazolium bromide (MTT) assay. All procedures were conducted aseptically in biological safety cabinet (ESC II series, Erla Technologies). The procedure was carried out according to the standard methods from Mosmann (1983) and Riss et al. (2016). In a 96-well plate an approximate $100 \mu \mathrm{L}$ of $5 \times 10^{6} \mathrm{cells} / \mathrm{mL}$ were seeded in each well, in triplicate. Subsequently, a serial dilution of apigenin, luteolin and quercetin were prepared in different concentrations $(6.25,12.5,25,50,100,200$, and $400 \mu \mathrm{g} / \mathrm{mL})$. The diluted solutions of apigenin, luteolin and quercetin were transferred to the seeded cells in the 96-well plate. The seeded cells were incubated for $24 \mathrm{~h}$ supplied with $5 \%$ $\mathrm{CO}_{2}$ in a humidified incubator at $37^{\circ} \mathrm{C}$. Further, $20 \mu \mathrm{L}$ of 3-(4,5-dimethylthiazol-2-yl)-2,5-diphenyltetrazolium bromide (MTT, $5 \mathrm{mg} / \mathrm{mL}$ ) was added to each cells in the absence of light and incubated for a period of $3 \mathrm{~h}$, covered with aluminium foil. After incubation, $50 \mu \mathrm{L}$ of DMSO was added to each well to dissolve the formazan crystals formed and incubated for another $15 \mathrm{~min}$ in the incubator. The absorbance was read at a wavelength of $570 \mathrm{~nm}$ using the Enzyme Linked Immunosorbent Assay (ELISA) micro plate reader (infinite M200PRO, TECAN, Switzerland). The discoloration is directly proportional to the number of viable cells. The percentage of NK cell proliferation was calculated using the following formula (Manosroi et al. 2003):

Proliferation $(\%)=\left[\left(\mathrm{OD}_{\text {sample }}-\mathrm{OD}_{\text {control }}\right) / \mathrm{OD}_{\text {control }}\right] \times 100$ 


\section{STATISTICAL ANALYSIS}

The results were expressed as mean \pm standard deviation (SD) of three independent experiments in three replicates. Statistical differences between the control and the flavonoid compounds with different concentrations to the cell line were analyzed using one-way analysis of variance (ANOVA), followed by Dunnett's multiple comparison tests using the GraphPad Prism 6.0 program. All values were considered to be statistically significant at $P<0.05$ and the levels of significance were grouped according to three types: $* P<0.05,{ }^{*} P<<0.01, * * * P<0.001$.

\section{RESULTS AND DISCUSSION}

By increasing the concentration of apigenin, luteolin and quercetin, the percentage of NK cells proliferation was increased (Figures 1, 2 \& 3). A significant increase in NK cell proliferation was observed at $25 \mu \mathrm{g} / \mathrm{mL}$ of apigenin (Figure 1) and luteolin (Figure 2) and slightly lower for quercetin which was at $6.25 \mu \mathrm{g} / \mathrm{mL}$ (Figure 3). Lower concentration of quercetin is needed to stimulate the proliferation of NK cells as compared to apigenin and luteolin. However, it was noticeable at $100 \mu \mathrm{g} / \mathrm{mL}$ that all studied compounds were found to attain highest percentage of cell's proliferation. Thus, the concentration of $100 \mu \mathrm{g} / \mathrm{mL}$ was selected as the optimal concentration for maximum proliferation of NK cells. The percentage of cell proliferation significantly declined when all flavonoids exceed the concentration of $100 \mu \mathrm{g} / \mathrm{mL}$. When analyzed statistically, the decline of NK cells proliferation at higher dose appeared to be insignificant $(p=0.45)$ prior to comparison between 100 and $200 \mu \mathrm{g} / \mathrm{mL}$ of apigenin concentration (Figure 4). However, a significant relationship was observed in 100 and $400 \mu \mathrm{g} / \mathrm{mL}$ apigenin concentration ( $p=0.0083)$. For luteolin, a spike in NK cell's proliferation was observed at higher concentrations of 200 and $400 \mu \mathrm{g} / \mathrm{mL}(\mathrm{p}=0.0149$ and 0.007$)$ when compared with $100 \mu \mathrm{g} / \mathrm{mL}$ of luteolin concentration (Figure 5). In contrast, the reduction in NK cell's proliferation at higher doses concentration of quercetin was found to be minimal and posed insignificant relation at 200 and 400 $\mu \mathrm{g} / \mathrm{mL}(\mathrm{p}=0.0987$ and 0.347 , respectively) using 100 $\mu \mathrm{g} / \mathrm{mL}$ concentration as its reference (Figure 6). Based on this analysis, apigenin provides greater level of NK cells proliferation compared to the other two flavonoid compounds.

Immune cells are critical for their use in wiping out invading microorganisms and abnormally transformed cells in host. Immune-based-therapy has been tested via in vivo and in vitro as a solution to cancer treatment. Natural killer cells are well known for its ability to curb cancerous cells (Miller \& Lanier 2019). One of the growing agenda in cancer research is to find a way to grow NK cells exponentially in human body. Several experiments conducted found that the effect of interleukins facilitating NK cells proliferation was accompanied with side effects that include a fatal capillary leakage. Such occurrence deters the use of interleukins for application related to NK proliferation and anti-cancer therapy (KaiFeng et al. 2011). At this point of study, various flavonoids compound have been researched on its capacity to activate NK cells but such findings are still at pre-mature as it is imperative to understand the adaptability of apigenin, luteolin and quercetin as a function for cytoproliferative or cytotoxic to the NK cells.

For in vitro study, the flavonoids have been useful in enhancing the proliferative effect of NK cells based on the dose determined for the immune-based cancer therapy. All studied flavonoids (apigenin, luteolin, and quercetin) exhibit an enhance NK cells proliferation in which the percentage of NK cells proliferation increased when the cells were incubated with apigenin, luteolin and quercetin under series of dose up to $100 \mu \mathrm{g} / \mathrm{mL}$. However, the NK cells proliferation continued to decline beyond the concentration. In quercetin, only a small decline of proliferation was observed when the concentration reached more than $100 \mu \mathrm{g} / \mathrm{mL}$ whereas the other two flavones were significantly affected for reduced cell proliferation. The stimulatory effect of apigenin was found to be highest (value $309 \%$ ) at $100 \mu \mathrm{g} / \mathrm{mL}$ while the least stimulatory effect of quercetin could be achieved at $34 \%$ at similar dose. The minimum dose required for apigenin and luteolin to enhance the proliferation of $\mathrm{NK}$ cells was $25 \mu \mathrm{g} / \mathrm{mL}$ which lasted for $24 \mathrm{~h}$.

The immunomodulatory and cytoproliferative effect of polyphenols are reportedly linked to the availability of the hydroxyl $(-\mathrm{OH})$ group present in these compounds. In this case, the stimulatory activity of enzyme system or electron transferring system could be affected due to the presence of hydroxyl group which activates immune cells (Manosroi et al. 2003). Apigenin contains 3 hydroxyl groups, in which the first group was located in position 4 of $\mathrm{B}$ ring, and the other two groups located in the $5^{\text {th }}$ and $7^{\text {th }}$ carbon atoms of A ring. These hydroxyl groups involve in the activation of NK cell enzyme system which subsequently influenced the cell proliferation. Unlike apigenin, luteolin has 4 hydroxyl groups (with an extra-OH group in carbon atom position 3 of $\mathrm{B}$ ring) but showing less proliferative effect when compared to apigenin. The lowest proliferative effect was achieved by quercetin comprising $5-\mathrm{OH}$ groups (located at $5^{\text {th }}$ and $7^{\text {th }}$ carbon atom of $\mathrm{A}$ ring, $4^{\text {th }}$ and $5^{\text {th }}$ carbon atom of $\mathrm{B}$ ring and at $3^{\text {rd }}$ carbon atom of $\mathrm{C}$ ring, respectively). Based on this observation, the increase number of hydroxyl groups in flavonoid would further reduced its effect in promoting NK cell proliferation. Accordingly, the increasing numbers of-OH groups may affect the optimal binding capacity of flavonoids via specific binding sites. The binding of flavonoids are important for NK cell proliferation and promotes less mitogen effect. Other findings have reported a different outcome to the use of flavonoid in which luteolin has higher proliferative effect than apigenin (Kilani- 
Jaziri et al. 2015). The reason behind this is because of the nature of NK cells used in the experiment whereby NK-92 cell line used in the present study was derived from human peripheral blood different to Kilani-Jaziri et al. (2015) that uses non-adherent splenocytes from $\mathrm{BALB} / \mathrm{c}$ mice as the source of NK cells. Because of these differences, the nature of NK cells may be the factor that makes the immune cells responded differently to the stimulatory effect of flavonoids. The differences of dose used to stimulate NK cells proliferation may also lead to different effect. In Kilani-Jaziri et al. (2015) higher dose of flavonoid (10 and $25 \mu \mathrm{M} / \mathrm{L}$ ) was used whereas lower dose of flavonoid (0.1-1.5 $\mu \mathrm{M} / \mathrm{L}$ range) was implemented in this study.

The maximum stimulatory effects of these compounds are found to be $100 \mu \mathrm{g} / \mathrm{mL}$. Upon increasing the dose of flavonoids to 200 and $400 \mu \mathrm{g} / \mathrm{mL}$, there was a decline in NK cell proliferation with quercetin at minimal $(p>0.05)$. Both apigenin and luteolin observed significance $(p<0.05)$ with 200 and $400 \mu \mathrm{g} / \mathrm{mL}$. The reason for a decline in cell proliferation at higher dose could be factorized by the change of osmolality in culture media. Different flavonoid compounds may possess different osmolality as they may contain different chemical composition and concentration that change the osmolality of the media. A higher cell density of culture could also be a reason that would interrupt cells proliferation. The culture cells viability depends on the optimal concentration of cells as well as sufficient nutrients to meet the requirements of growing cells. If such requirement was not followed, the rate of cell viability could gradually decline and there will be an increase in the number of cell death as a reason to high cell density and lack of nutrients.

Our work suggests that the proliferative effect of NK cells via flavonoids could be based on the matter of cell replication (mitosis). These flavonoids might occupy some chemical properties which stimulate the proliferative process of NK cells. Moreover, an anti-oxidant driven mechanism of flavonoids could also function to scavenge free radicals and reactive oxygen species. Free radicals are highly toxic to cell proliferation and by alleviating the level of these toxic molecules in cell microenvironment, the NK cells proliferation could be improved. Other finding also implored on the use of flavonoids to neutralize and scavenge superoxides and peroxynitrites produced by cells (Hanasaki et al. 1994).

Diet rich in flavonoids have a better chance to lower the risk of having contracting diseases which includes cancer due to their influence on immune system (Benavente-García \& Castillo 2008; Sanbongi et al. 1997). The increasing number of NK cells could boost human's immunity and that can be achieved by consuming and using flavonoid in daily basis.

Our findings are found to be consistent with KilaniJaziri et al. (2015) where the researchers reported that murine splenocytes proliferation was achieved by apigenin and luteolin. Similar findings were endorsed by treating the splenocytes with other forms of flavonoids such as caffeic, ferulic, and p-coumaric phenolic acids (Kilani-Jaziri et al. 2017). There is also a report on doubleblinded, placebo-controlled, randomised trial which indicates zero effect of innate immune function in response to the quercetin supplementation for a period of 12 weeks (Heinz et al. 2010).

This study had reached to a point of identifying the underlying mechanisms of flavonoid-induced NK cell proliferation. The possible cellular mechanism pointing to the decline of NK cells growth at higher dose of flavonoids has yet to be understood and is a subject taken for further studies.

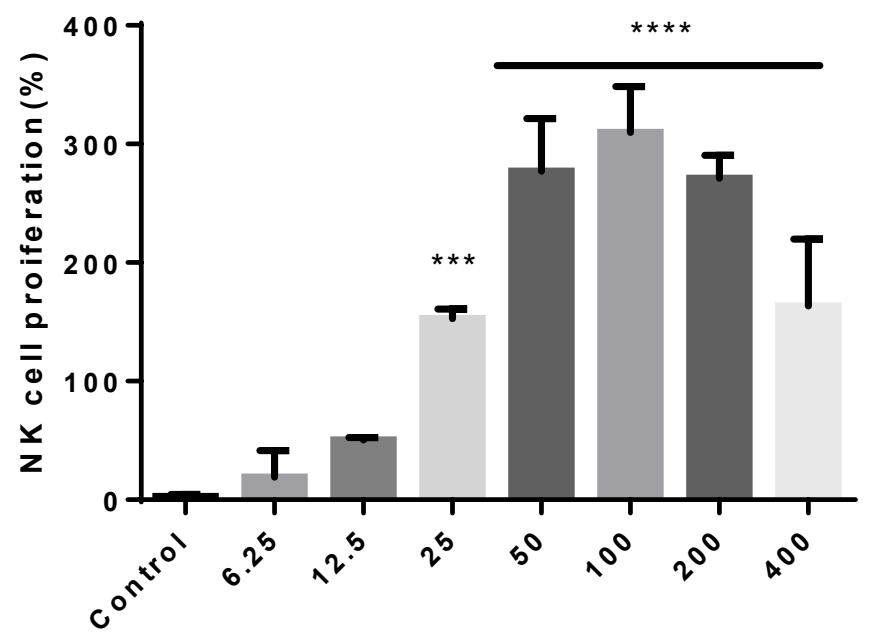

Apigenin concentration $(\mu \mathrm{g} / \mathrm{m} \mathrm{I})$

FIGURE 1. Effects of apigenin concentrations on natural killer (NK) cell proliferation. NK cells in each well were incubated overnight at different concentrations of apigenin $(6.25,12.5,25,50,100,200$, and $400 \mu \mathrm{g} / \mathrm{mL}$ ). The control cells were incubated with complete $\alpha$-minimal essential medium (MEM) media and phosphate buffer saline (PBS) only. 3-(4,5-dimethylthiazol-2-yl)-2,5-diphenyltetrazolium bromide (MTT) assay was done to assess NK cell proliferation. The data represents mean percentage of proliferation $( \pm$ standard deviation, SD) from three independent experiments. *Value significantly different compared with that of negative control $(* * * \mathrm{p}<0.001$ and $* * * * p<0.0001)$ 


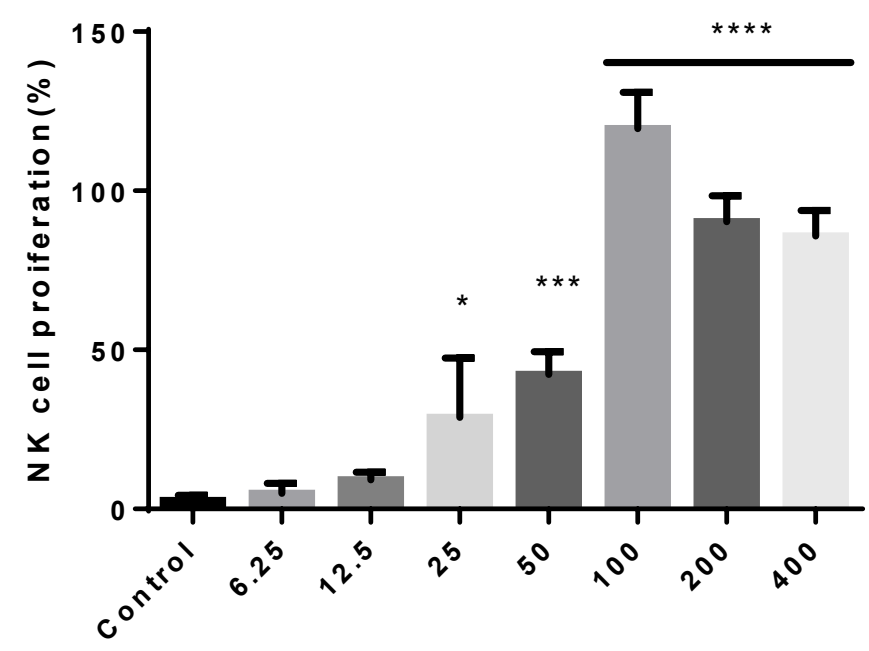

Luteolin concentration $(\mu \mathrm{g} / \mathrm{mI})$

FIGURE 2. Effects of luteolin concentrations on natural killer (NK) cell proliferation. The data represents mean percentage proliferation ( \pm standard deviation, SD) from three independent experiments. *Value significantly different compared with that of negative control $\left(* \mathrm{p}<0.05,{ }^{* * *} \mathrm{p}<0.001\right.$ and $\left.* * * * \mathrm{p}<0.0001\right)$

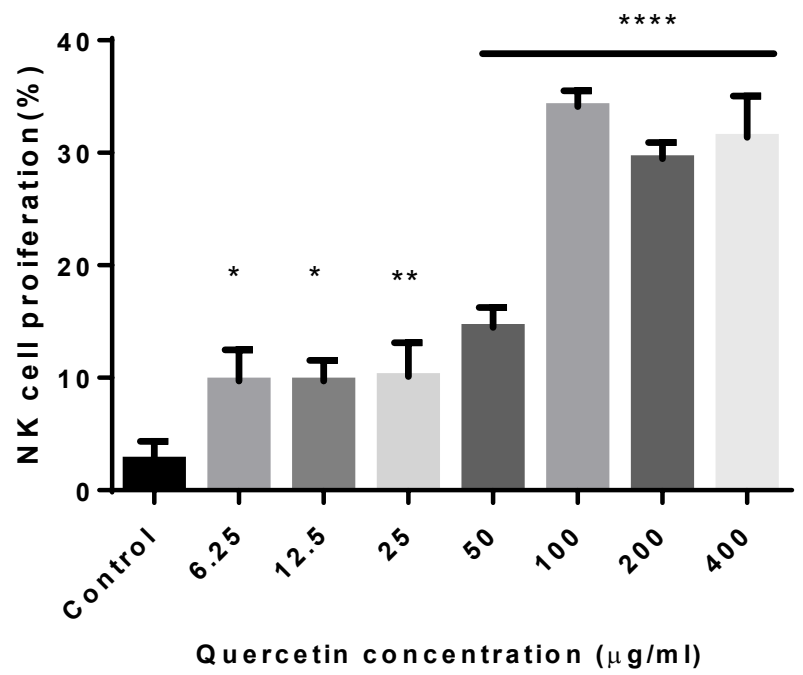

FIGURE 3. Effects of quercetin concentrations on natural killer (NK) cell proliferation. The data represents mean percentage proliferation ( \pm standard deviation,

$\mathrm{SD})$ from three independent experiments. *Value significantly different compared with that of negative control $(* \mathrm{p}<0.05, * * \mathrm{p}<0.01$ and $* * * * p<0.0001)$ 


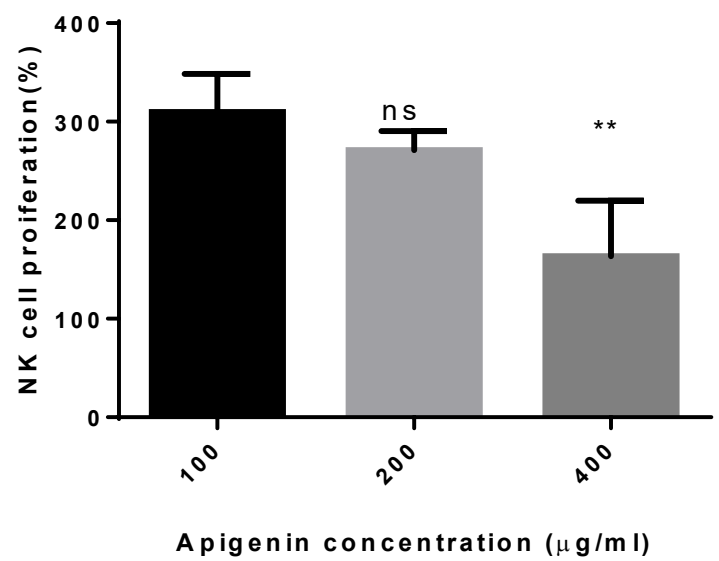

FIGURE 4. Comparison of higher doses $(100,200$, and $400 \mu \mathrm{g} / \mathrm{mL})$ of apigenin on natural killer (NK) cell's proliferation. The data represents mean percentage of proliferation ( \pm standard deviation, SD) from three independent experiments. *Value significantly different compared with $100 \mu \mathrm{g} / \mathrm{mL}$ concentration of apigenin $(* * \mathrm{p}<0.01$ and $\mathrm{ns}=$ not significant $)$

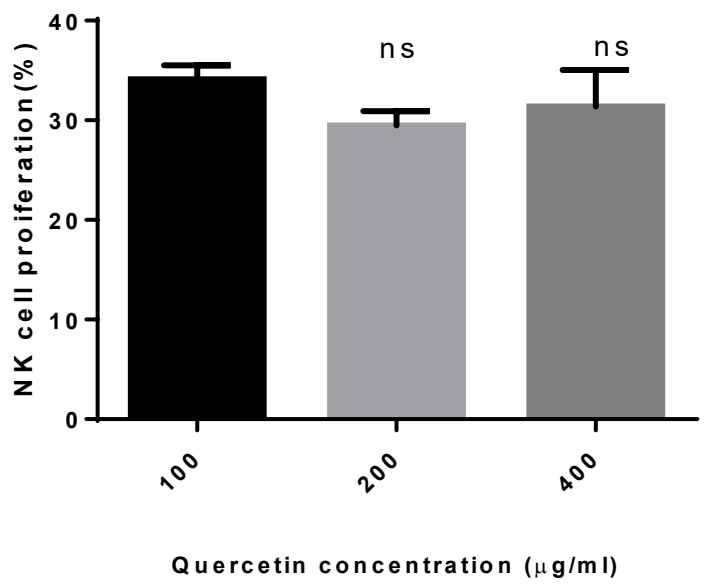

FIGURE 5. Comparison of higher doses (100, 200 and $400 \mu \mathrm{g} / \mathrm{mL})$ of luteolin on natural killer (NK) cell's proliferation. The data represents mean percentage of proliferation ( \pm standard deviation, SD) from three independent experiments. *Value significantly different compared with $100 \mu \mathrm{g} / \mathrm{mL}$ concentration of luteolin $(* \mathrm{p}<0.05$, and $* * \mathrm{p}<0.01)$

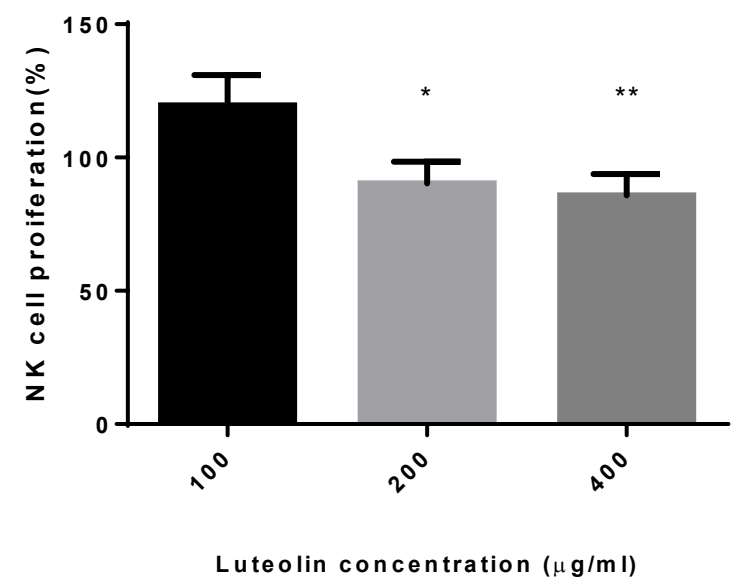

FIGURE 6. Comparison of higher doses (100, 200 and $400 \mu \mathrm{g} / \mathrm{mL})$ of quercetin on natural killer (NK) cell's proliferation. The data represents mean percentage of proliferation ( \pm standard deviation, $S D)$ from three independent experiments. *Value significantly different compared with $100 \mu \mathrm{g} / \mathrm{mL}$ concentration of quercetin (ns = not significant) 


\section{CONCLUSION}

In conclusion, apigenin, luteolin, and quercetin are a group of flavonoids capable to increase the proliferation of NK cells at lower doses. Apigenin provides strongest stimulatory effect on NK cell proliferation as compared to the other two flavonoids. This observation provides an insight to the unexplored benefits of flavonoid especially in promoting its use for cancer treatment, whereby the use of flavonoids can be subjected to increase the number of NK cells among cancer patients.

\section{ACKNOWLEDGEMENTS}

The authors would like to express their sincere gratitude to Dr Abdi Wira Septama and Miss Nik Nurul Najha for their scientific opinion and guidance and all laboratory staffs for their kind assistance. The research is funded by the Fundamental Research Grant Scheme (FRGS), project code RR236(FRGS/2017/SKK06/UNISZA/01/2) and approved by Ministry of Education, Malaysia.

\section{REFERENCES}

Artis, D. \& Spits, H. 2015. The biology of innate lymphoid cells. Nature 517(7534): 293-301.

Benavente-García, O. \& Castillo, J. 2008. Update on uses and properties of citrus flavonoids: New findings in anticancer, cardiovascular, and anti-inflammatory activity. Journal of Agricultural and Food Chemistry 56(15): 6185-6205.

Darien, B.J. \& Godbee, R.G. 2014. Morinda citrifolia based formulations for regulating $\mathrm{T}$ cell immunomodulation in neonatal stock animals. United States Tahitian Noni International, Inc. 8652546.

Exon, J.H., Magnuson, B.A., South, E.H. \& Hendrix, K. 1998. Dietary quercetin, immune functions and colonic carcinogenesis in rats. Immunopharmacology and Immunotoxicology 20(1): 173-190.

Grudzien, M. \& Rapak, A. 2018. Effect of natural compounds on NK cell activation. Journal of Immunology Research 4868417: 1-11.

Hanasaki, Y., Ogawa, S. \& Fukui, S. 1994. The correlation between active oxygens scavenging and antioxidative effects of flavonoids. Free Radical Biology and Medicine 16(6): 845-850.

Heinz, S.A., Henson, D.A., Nieman, D.C., Austin, M.D. \& Jin, F. 2010. A 12-week supplementation with quercetin does not affect natural killer cell activity, granulocyte oxidative burst activity or granulocyte phagocytosis in female human subjects. The British Journal of Nutrition 104(6): 849-857.

Ismail, N., Abdullah, H., Seidel, V. \& Rotondo, D. 2018. Human natural killer (NK) cell activation by luteolin from Brucea javanica leaves. Journal of Cancer Research and Experimental Oncology 10(2): 10-14.

Kai-Feng, W., Hong-Ming, P., Hai-Zhou, L., Li-Rong, S. \& Xi-Yan, Z. 2011. Interleukin-11-induced capillary leak syndrome in primary hepatic carcinoma patients with thrombocytopenia. BMC Cancer 11(204): 1-5.

Kilani-Jaziri, S., Mokdad-Bzeouich, I., Krifa, M., Nasr, N., Ghedira, K. \& Chekir-Ghedira, L. 2017. Immunomodulatory and cellular anti-oxidant activities of caffeic, ferulic, and p-coumaric phenolic acids: A structure-activity relationship study. Drug and Chemical Toxicology 40(4): 416-424.

Kilani-Jaziri, S., Mustapha, N., Mokdad-Bzeouich, I., El Gueder, D., Ghedira, K. \& Ghedira-Chekir, L. 2015. Flavones induce immunomodulatory and anti-inflammatory effects by activating cellular anti-oxidant activity: A structure-activity relationship study. Tumor Biology 37(5): 6571-6579.

Lindqvist, C., Bobrowska-Hägerstrand, M., Mrówczyńska, L., Engblom, C. \& Hägerstrand, H. 2014. Potentiation of natural killer cell activity with myricetin. Anticancer Research 34(8): 3975-3979.

Manosroi, A., Saraphanchotiwitthaya, A. \& Manosroi, J. 2003. Immunomodulatory activities of Clausena excavata Burm. f. wood extracts. Journal of Ethnopharmacology 89(1): 155-160.

Miller, J.S. \& Lanier, L.L. 2019. Natural killer cells in cancer immunotherapy. Annual Review of Cancer Biology 3(1) 77-103.

Mosmann, T. 1983. Rapid colorimetric assay for cellular growth and survival: Application to proliferation and cytotoxicity assays. Journal of Immunological Methods 65(1-2): $55-63$.

Orange, J.S. 2013. Natural killer cell deficiency. Journal of Allergy and Clinical Immunology 132(3): 515-525.

Riss, T.L., Moravec, R.A., Niles, A.L., Duellman, S., Benink, H.A., Worzella, T.J. \& Minor, L. 2016. Cell viability assays. In Assay Guidance Manual, vol. 2004, edited by Sittampalam, G.S., Coussens, N.P., Brimacombe, K., Grossman, A., Arkin, M., Auld, D., Austin, C., Baell, J., Bejcek, B., Chung, T.D.Y., Dahlin, J.L., Devanaryan, V., Foley, T.L., Glicksman, M., Hall, M.D., Hass, J.V., Inglese, J., Iversen, P.W., Kahl, S.D. Kales, S.C., Lal-Nag, M., Li, Z., McGee, J., McManus, O., Riss, T., Trask Jr., O.J., Weidner, J.R., Xia, M. \& Xu, X Bethesda: Eli Lilly \& Company and the National Center for Advancing Translational Sciences. pp. 355-386.

Sanbongi, C., Suzuki, N. \& Sakane, T. 1997. Polyphenols in chocolate, which have antioxidant activity, modulate immune functions in humans in vitro. Cellular Immunology 177(2): 129-136.

Thomson, G. 2007. The Health Benefits of Traditional Chinese Plant Medicines: Weighing the Scientific Evidence. Australia: Rural Industries Research and Development Corporation. p. 86.

Aung Myo Oo@Mohd Hasym, Nasir Mat Nor*, Liyana Hazwani Mohd Adnan, Nor Zidah binti Ahmad, Nik Nurul Najihah \& Nordin Simbak

Faculty of Medicine

Universiti Sultan Zainal Abidin

20400 City Campus

Kuala Terengganu, Terengganu Darul Iman Malaysia 
Abdi Wira Septama

Research Center for Chemistry

Indonesian Institute of Sciences

Kawasan PUSPIPTEK Serpong

Tangerang Selatan, Banten 15314

Indonesia

Ohn Mar Lwin

Physiology unit

Faculty of Medicine

Lincoln University College Kelana Jaya

47301, Petaling Jaya, Selangor Darul Ehsan

Malaysia
*Corresponding author; email: nasirmnor@unisza.edu.my

Received: 16 June 2020

Accepted: 10 August 2020 